\title{
Regeneration and Preliminary Characterization of Asian and African Okra (Abelmoschus spp.) Germplasm
}

\begin{abstract}
Idi Saidou Sani,
University of Diffa, Faculty of Agronomic Sciences, Department of Vegetable Production, UMR : Aridoculture and Oasis Crops, Diffa, Niger

\section{Moustapha Grema,}

University of Diffa, Faculty of Agronomic Sciences, Department of Vegetable Production, UMR : Aridoculture and Oasis Crops, Diffa, Niger Abdou Moumouni University of Niamey, Faculty of Technologic Sciences,

Department of Biology, Garba Mounkaila Laboratory, Niamey, Niger
\end{abstract}

\section{Kumar Sanjeet,}

AVRDC - The World Vegetable Center, AVRDC-ICRISAT Project, Station de Sadoré/Niamey-Niger

\section{Bakasso Yacoubou,}

Abdou Moumouni University of Niamey, Faculty of Technologic Sciences,

Department of Biology, Garba Mounkaila Laboratory, Niamey, Niger

\section{Ali Mahamane,}

University of Diffa, Faculty of Agronomic Sciences, Department of Vegetable Production, UMR : Aridoculture and Oasis Crops, Diffa, Niger Abdou Moumouni University of Niamey, Faculty of Technologic Sciences,

Department of Biology, Garba Mounkaila Laboratory, Niamey, Niger

\section{Abstract}

The morphological variability of 56 okra (Abelmoschus spp.) Accessions was evaluated over two years (2008 and 2009). Ten (10) agromorphological characters were evaluated in the Sadore station in Niger. The hierarchical ascendant classification $(\mathrm{CAH})$ and the discriminant factor analysis (AFD) revealed four groups (GI, GII, GIII and GIV). The accessions in groups I and IV have high values of Lfm, Dfm, Height, and Nloc, Nepi and cons by low values. However, Flo or Fruct values are relatively higher in accessions of group III and IV than in accessions of group I. Similarly, accessions of group II have higher values in Flo and Fruct than group II. However, accessions of group II are much later in terms of which accessions in group I, which, in turn, have lower values in Flo and Fruct, so these are 
compared to those of Group II. The results show that the most discriminating variables that make it possible to describe Variability among the groups identified are the diameter of mature fruits (Dfm), Plant height (Height) and branch of plant number (Nbrch). The characters analyzed can thus constitute basic criteria to differentiate accessions from other regions of West Africa and serve for a study of variability between the remains of okra accessions collected in Niger. Opportunities for improvement can also be considered to identify varieties that have a high adaptive potential due to climate change.

Keywords: Abelmoschus spp, morphological variability, accessions, okra

\section{Introduction}

Okra (Abelmoschus spp.) is important vegetable crop in the developing and less developed countries of Asia and Africa. Among four known domesticated species of the genus Abelmoschus, A. esculentus is most widely cultivated for its edible pods in South and East Asia, West Central and East Africa, and the southern USA. The other cultivated species are A. caillei (edible leaves and pods) in humid forest zone of West Africa (Siemonsma, 1982), A. manihot (edible leaves) in Papua New Guinea and South Pacific Islands and A. moschatus (seeds for ambretee and animism practices) in India and South Togo and Benin (Hamon et al., 1995). Okra has potential to significantly contribute to increased livelihoods of both rural and urban populations (Kumar et al., 2011). This is especially because of its robust nature, dietary fibers and distinct seed protein balanced in both lysine and tryptophan amino acids (unlike the proteins of cereals and pulses) it provides (DS/MDA, 2008). Okra has also been predicted as an industrial crop (Camciuc et al., 1998). However, until recently, no attention was paid to its improvement in the international research program in past (Duzyaman, 1997). During 2007, we initiated okra improvement activities and in this report results on preliminary morphological characterization of some germplasm accessions are being presented and discussed.

\section{Material and methods}

This study had been conducted at ICRISAT station of Sadoré (Situated in the south-west part of Niger at $45 \mathrm{~km}$, south of Niamey) during two rainy seasons (2008 and 2009). The minimal and maximal temperature means that have been saved during these two seasons were respectively $23.2^{\circ} \mathrm{C}$ and 35.5 ${ }^{\circ} \mathrm{C}$ for 2008 year; $22.8{ }^{\circ} \mathrm{C}$ and $35.18{ }^{\circ} \mathrm{C}$ for 2009 year. The rainfall was also respectively $480.6 \mathrm{~mm}$ and $515.6 \mathrm{~mm}$ for 2008 and 2009 .

Fifty-six accessions of three species, namely, A. esculentus, A. manihot var. tetraphyllus and A. manihot var. manihot (re-assigned as A. caillei after Siemonsama, 1982) originated from 12 countries of Asia and Africa were 
utilized (Table 1). These accessions were introduced from National Plant Germplasm System (NPGS), United States and AVRDC - The World Vegetable Center, Taiwan during 2007 and comprised of 48 locally collected genotypes, six improved open pollinated varieties and two hybrids $\left(\mathrm{F}_{1}\right)$. These accessions were part of about 250 germpalsm accessions regenerated by AVRDC/ICRISAT (International Crops Research Institute for the Semi Arid Tropics) Project in Niger.

Table1: Origin of different okra lines

\begin{tabular}{|l|l|l|}
\hline Origine & Varieties & Code_Variéties \\
\hline Bangladesh & TOT-0546 & $1 \mathrm{e}$ \\
\hline Bangladesh & TOT-4676 & $2 \mathrm{e}$ \\
\hline India & GRIF 12789 & $3 \mathrm{t}$ \\
\hline India & GRIF 12790 & $4 \mathrm{t}$ \\
\hline India & Grif 13133 & $5 \mathrm{e}$ \\
\hline India & Grif 13149 & $6 \mathrm{e}$ \\
\hline India & Grif 13164 & $7 \mathrm{e}$ \\
\hline India & Grif 13191 & $8 \mathrm{e}$ \\
\hline India & Grif 13433 & $9 \mathrm{e}$ \\
\hline India & Grif 13435 & $10 \mathrm{e}$ \\
\hline India & PI 116453 & $11 \mathrm{e}$ \\
\hline India & PI 116454 & $12 \mathrm{e}$ \\
\hline India & PI 249620 & $13 \mathrm{e}$ \\
\hline India & PI 370028 & $14 \mathrm{e}$ \\
\hline India & PI 370029 & $15 \mathrm{e}$ \\
\hline India & PI 548700 & $16 \mathrm{e}$ \\
\hline India & RCA-1 & $17 \mathrm{e}$ \\
\hline India & RAKSHAK F1 & $18 \mathrm{e}$ \\
\hline Malaysia & TOT-2742 & $19 \mathrm{e}$ \\
\hline Philippines & TOT-2788 & $20 \mathrm{e}$ \\
\hline Philippines & TOT-3133 & $21 \mathrm{e}$ \\
\hline Philippines & TOT-3134 & $22 \mathrm{e}$ \\
\hline Philippines & TOT-3139 & $23 \mathrm{e}$ \\
\hline Philippines & TOT-3142 & $24 \mathrm{e}$ \\
\hline Philippines & TOT-3143 & $25 \mathrm{e}$ \\
\hline Philippines & TOT-3442 & $26 \mathrm{e}$ \\
\hline Taiwan & TOT-6000 & $27 \mathrm{e}$ \\
\hline Taiwan & TOT-6018 & $28 \mathrm{e}$ \\
\hline & & \\
\hline & & \\
\hline
\end{tabular}

\begin{tabular}{|l|l|l|}
\hline Origine & Varieties & Code_Variéties \\
\hline Thailand & TOT-3854 & $29 \mathrm{e}$ \\
\hline Thailand & TOT-3855 & $30 \mathrm{e}$ \\
\hline Thailand & TOT-3851 & $31 \mathrm{e}$ \\
\hline Thailand & TOT-3859 & $32 \mathrm{e}$ \\
\hline Benin & PI 496944 & $33 \mathrm{c}$ \\
\hline Benin & PI 496945 & $34 \mathrm{c}$ \\
\hline Benin & PI 496452 & $35 \mathrm{e}$ \\
\hline Benin & PI 496957 & $36 \mathrm{e}$ \\
\hline Benin & PI 496954 & $37 \mathrm{e}$ \\
\hline Benin & PI 496955 & $38 \mathrm{e}$ \\
\hline Cameroon & PI 535944 & $39 \mathrm{e}$ \\
\hline Ghana & PI 497026 & $40 \mathrm{c}$ \\
\hline Ghana & PI 280063 & $41 \mathrm{e}$ \\
\hline Ghana & PI 496620 & $42 \mathrm{e}$ \\
\hline Ghana & PI 496616 & $43 \mathrm{e}$ \\
\hline Ghana & PI 496617 & $44 \mathrm{e}$ \\
\hline Ghana & PI 496618 & $45 \mathrm{e}$ \\
\hline Ghana & PI 496619 & $46 \mathrm{e}$ \\
\hline Guinea & PI 496640 & $47 \mathrm{e}$ \\
\hline Guinea & PI 496634 & $48 \mathrm{e}$ \\
\hline Guinea & PI 496631 & $49 \mathrm{e}$ \\
\hline Guinea & PI 496635 & $50 \mathrm{e}$ \\
\hline Guinea & PI 496639 & $51 \mathrm{e}$ \\
\hline Niger & KONNI & $52 \mathrm{e}$ \\
\hline Niger & GAYA & $53 \mathrm{e}$ \\
\hline Niger & TERA & $54 \mathrm{e}$ \\
\hline Senegal & OKML-LIMA & \\
\hline Senegal & VOLTA & $56 \mathrm{e}$ \\
\hline & & \\
\hline & & \\
\hline
\end{tabular}

The experiment was conducted according to a Fisher block device completely randomized with four repetitions. In each block, an accession is represented by twenty plants which are separated by a distance of $0.3 \mathrm{~m}$ between the poquet, and a distance of $0.5 \mathrm{~m}$ between the line. The lines of the 
same block are separated by one meter from each other and successive blocks of two meters.

Twenty plants of each accession were raised during two rainy seasons (2008 and 2009) and observations were recorded on 10 morphological descriptors. Five plants in each accession were randomly selected to record observations on plant height (Height) and number of branch per plant (Nbrch). Three pods from each plant were used to determine length of immature (horticultural maturity) fruit (Ljm), diameter of immature fruits (Djf), length of mature fruit $(\mathrm{Lfm})$, diameter of mature fruits $(\mathrm{Dfm})$, number of locule (Nloc) and number of epicalyx (Nepi). Days to 50\% flowering (Flo) and days to $50 \%$ fruiting (Fru) were determined on population basis. Using two season's data, the average clustering method was used with mean of two seasons data on ten quantitative characters to prepare dendrogram (Fig. 1).

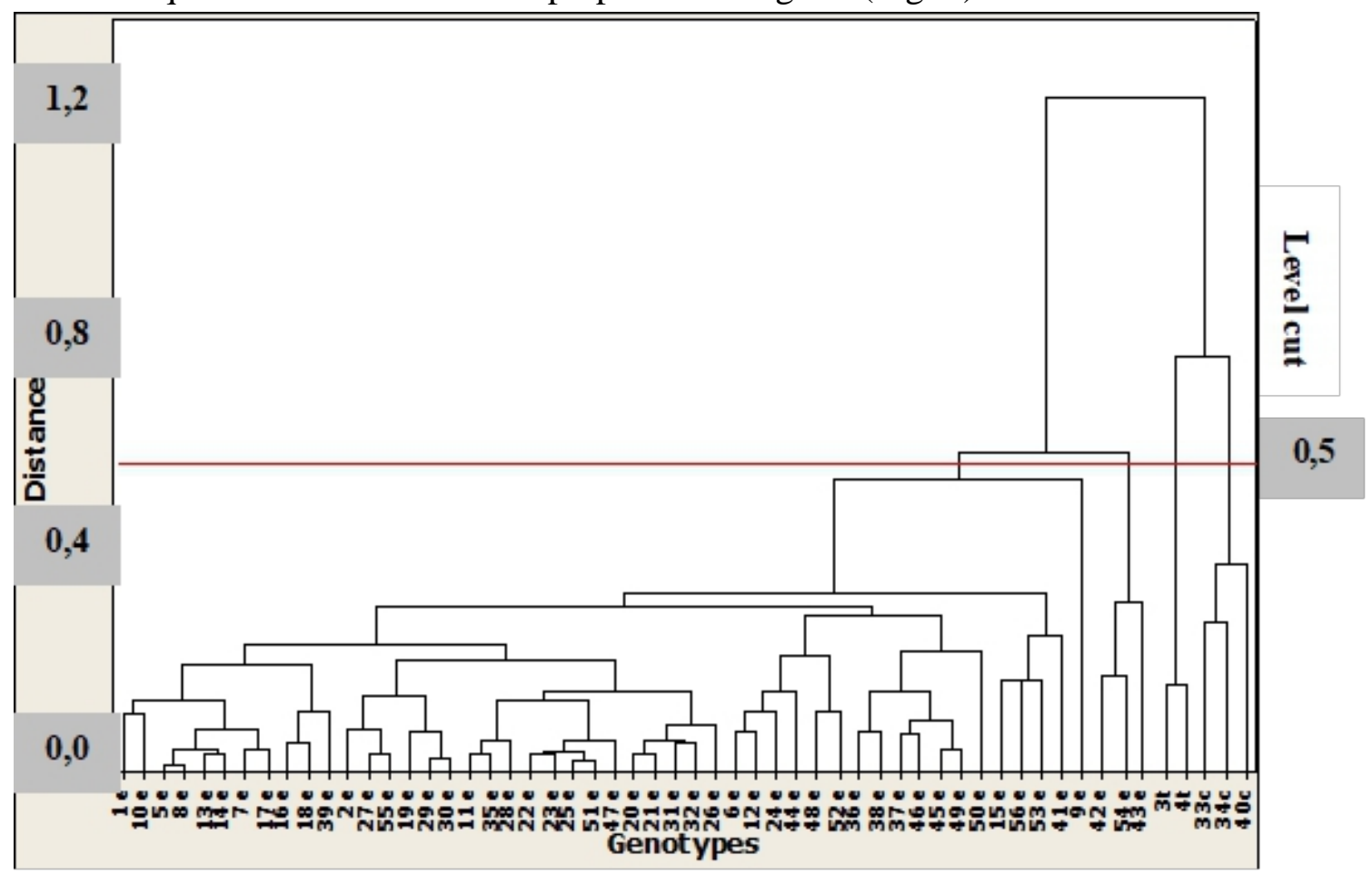

Fig.1: Dendrogram of 56 okra genotypes on the basis of genetic distance

The factorial analysis discriminant had been making to discriminat the different group obtained after HCA analysis. For all analysis data, two software were being used. The Minitab14 software for preparing dendrogram and XLSTAT-pro-V7.5.2 software for Factorial Analysis Discriminant (FAD). 


\section{Results}

The dendrogram resulted from average linkage clustering of 10 quantitative data allowed a very clear-cut grouping of three Abelmoschus spp. (Fig 1). The first and second set of clusters included all 51 accessions of $A$. esculentus. The first cluster had 48 accessions collected from different countries of Asia and West and Central Africa (WCA), while the second cluster had only three accessions collected from West Africa, two from Ghana and one from Niger. The third cluster comprised of two accessions of $A$. manihot var. tetraphyllus from India and the fourth cluster had three A. caillei accessions collected from Benin and Ghana (Fig.1 \& Table 1). Although dendrogram clearly separate accessions according to species, clustering of accessions accordingly to geographical origin and accession type (local landrace, improved cultivar and hybrids) could not be observed.

\section{- Results of discriminant analysis on four groups already identified}

The results of the FDA applied to data from four groups identified are first to feel the Mahalanobis distances (McLachlan, 1992) between the groups identified by the HCA and their significance (Table 2). The results in Table 2 indicate that there is a very highly significant difference 0.0001 between the 4 groups on the basis of all the variables considered. Otherwise, all the variables have contributed to discriminate the 4 groups. These results are confirmed by the multivariate test through statistical Wilks' Lambda (probability<0.004).

Table 2. Test results of discrimination by Mahalanobis distance

\begin{tabular}{llllll}
\hline & Grp I & Grp II & Grp III & Grp IV \\
\hline Grp I & 0 & - & & - & - \\
Grp II & $164.1^{* * *}$ & 0 & & - & \\
Grp III & $135.7 * * *$ & $123.3^{* * *}$ & 0 & & - \\
Grp IV & $58.2^{* * *}$ & $237.8^{* * *}$ & $77.7 * * *$ & 0 & \\
\hline \multicolumn{7}{c}{ Significant up to $0.05 \%$}
\end{tabular}

Moreover, examination of the values of the F statistic of Fisher and coefficient of determination $\mathrm{R}^{2}$ indicated that the variables $\mathrm{Dfm}$, Height and Nbrch are more discriminating with $\mathrm{R}^{2}$ values relatively high compared with other variables (Table 2). 
Table2. Results of univariate tests and multivariate discriminant power groups by the variables: R-square values and significance.

\begin{tabular}{lccc}
\hline Variable & $\mathrm{R}^{2}$ & $\mathrm{~F}(3)^{*}$ & F Value \\
\hline Lfm & 0.338 & 33.978 & $<0.0001$ \\
Ljm & 0.238 & 34.879 & $<0.0001$ \\
Dfm & 0.514 & 16.372 & $<0.0001$ \\
Djf & 0.138 & 36.879 & $<0.0001$ \\
Flo & 0.192 & 72.938 & $<0.0001$ \\
Fruct & 0.160 & 91.068 & $<0.0001$ \\
Height & 0.631 & 10.118 & $<0.0001$ \\
Nbrch & 0.648 & 9.426 & $<0.0001$ \\
Nloc & 0.385 & 27.647 & $<0.0001$ \\
Nepi & 0.049 & 339.789 & $<0.0001$ \\
\hline Wilks' Lambda statistics & $($ ddl $=52$ & & $<0.0001$ \\
$(3)^{*}:$ ddl = 3 & & & \\
\hline
\end{tabular}

Height: Plant height; Nbrch : Number of branch per plant ; Ljm : length of immature (horticultural maturity); Djf : fruit diameter of immature fruits ; $\mathbf{L f m}$ : length of mature fruit; Dfm : diameter of mature fruits ; Nloc : number of locule ; Nepi : number of epicalyx ; Flo : Days to $50 \%$ flowering; Fruct : days to $50 \%$ fruiting

Moreover, examination of the eigenvalues of canonical axes and their significance (Table 3) showed only the first three canonical axes are significant (probability <0.0001) and concentrate all alone $(100 \%)$ information contained in the original variables.

Table3. Proportions of information concentrated on the canonical axes, canonical correlation and significance of canonical axes.

\begin{tabular}{rlll}
\hline Axes & Proportions & Cumulated proportion & Prob \\
\hline 1 & 82.269 & 82.269 & $<0.0001$ \\
2 & 16.543 & 98.812 & $<0.0001$ \\
3 & 1.188 & 100.000 & $<0.0001$ \\
\hline
\end{tabular}

The description of correlations between initial variables and the first discriminant axis (CAN1) revealed that only high values of Lfm, Dfm, Height, Nloc and Nepi are associated with axis 1. This trend is confirmed by the two discriminant axes CAN2 and CAN3. Indeed, in general, genotypes with high values in group Lfm, Dfm, Height, Nepi and Nloc are genotypes that have a high plant size, large number of bun and epicalyx locule but also a great mature fruit diameter (Table 4). Axes 1 and 2 already take into account the information contained in the axis 3 . Thus, only these two axes will be used to describe the 4 groups.

Table 4. Correlations between initial variables and discriminant axes.

\begin{tabular}{llll} 
& Can1 & Can2 & Can3 \\
\cline { 2 - 4 } Variables & $\mathbf{0 . 7 2 9}$ & -0.416 & 0.079
\end{tabular}




\begin{tabular}{llll} 
Ljm & 0.133 & 0.277 & 0.125 \\
Dfm & $\mathbf{0 . 6 5 9}$ & 0.222 & -0.288 \\
Djf & 0.323 & 0.477 & 0.113 \\
FLO & 0.358 & $\mathbf{0 . 8 9 6}$ & 0.069 \\
Fruct & 0.404 & $\mathbf{0 . 8 9 5}$ & 0.005 \\
Height & $\mathbf{0 . 5 8 7}$ & 0.192 & 0.124 \\
Nbrch & 0.233 & 0.377 & $\mathbf{0 . 7 8 2}$ \\
Nloc & $\mathbf{0 . 7 9 4}$ & 0.079 & 0.042 \\
Nepi & $\mathbf{0 . 9 5 9}$ & -0.273 & 0.021 \\
\hline
\end{tabular}

The projection of the 4 groups in the system of canonical axes 1 and 2 (Fig.2) indicates that the first canonical axis has a discriminatory power higher than the second canonical axis. Indeed, it may be noted that Group II is more distant from groups I and IV, closer to each other with respect to the axis 1, while groups III and IV are particularly discriminated against by the axis 2 . Groups I and IV are also discriminated against in some measure by the axes 2.

Thus, we conclude that individuals in groups I and IV have high values of Lfm, Dfm, Height, and Nloc, Nepi and cons by low values when considering parameters such as Flo or Fruct unlike individuals in group II. However, Flo or Fruct values are relatively higher in individuals of group III and IV than in individuals of group I. Similarly, individuals of group I have higher values in Flo and Fruct than group II. However, individuals of group II are much later Fruct Flo and values that individuals in group I, which, in turn, have lower values in Flo and Fruct, so these genotypes are much earlier compared to those of Group II. We can also say without risk of error that genotypes groups III and IV are much later (with a mean value $($ Flo $=120.0$ and Fruct $=130.0 ;$ Flo $=111.6$ and Fruct $=128.6$ respectively for group III and IV) on phenological traits of both varieties of okra species, compared to a group of genotypes that are much earlier (with value Average for genotypes of the said group are 50.575 and 58.775 respectively for Flo and The Fruct) Table 5. 


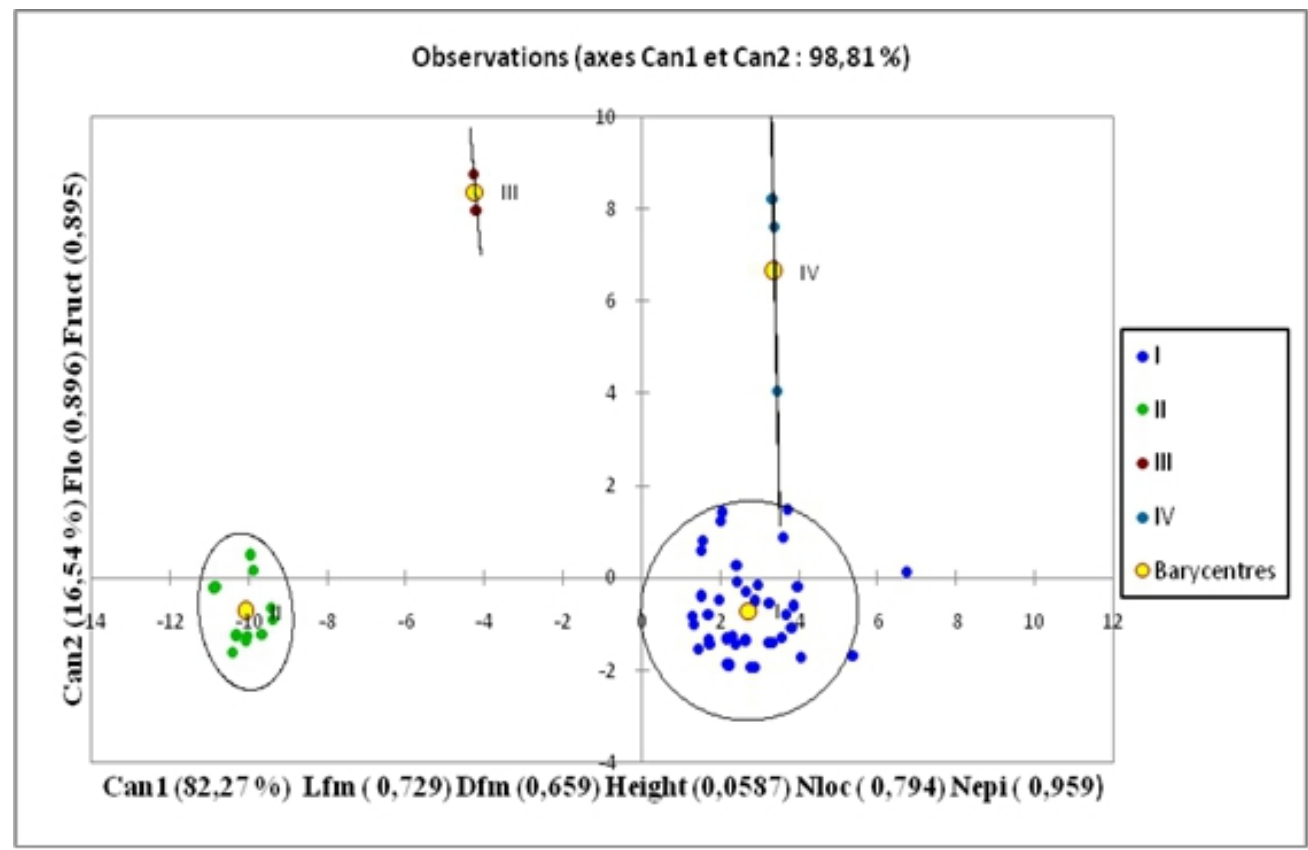

Fig.2: Projection of four groups in the plane formed by the first two canonical axes.

Table 5. Characteristics of the groups: mean values and standard deviations of the parameters by group, value of the Newmann Keuls statistic and their significance.

\begin{tabular}{|c|c|c|c|c|c|c|c|c|c|c|c|c|}
\hline \multirow{2}{*}{ Variables } & \multicolumn{2}{|c|}{ Grp I } & \multicolumn{2}{|c|}{ Grp II } & \multicolumn{2}{|c|}{ Grp III } & \multicolumn{2}{|c|}{ Grp IV } & \multicolumn{2}{|c|}{ Global } & \multicolumn{2}{|c|}{ Test statistics } \\
\hline & $\mathbf{m}$ & $\mathbf{s}$ & $\mathbf{m}$ & $\mathbf{s}$ & $\mathbf{m}$ & $\mathbf{s}$ & $\mathbf{m}$ & $\mathbf{S}$ & $\mathbf{m}$ & $\mathbf{S}$ & $\mathbf{F}$ & Prob \\
\hline Lfm & $14.938^{\mathrm{a}}$ & 2.24 & $7.277 b^{c}$ & 1.234 & $5.025^{\mathrm{c}}$ & 1.63 & $9.55^{\mathrm{b}}$ & 2.9 & $9.1975^{\mathrm{b}}$ & 4.250 & 162.990 & 0.055 \\
\hline Ljm & $14.932^{\mathrm{a}}$ & 1.03 & $7.259^{\mathrm{c}}$ & 2.522 & $5.02^{\mathrm{d}}$ & 1.13 & $8.989^{b}$ & 3.12 & $9.05^{\mathrm{b}}$ & 4.245 & 5446.647 & 0.090 \\
\hline Dfm & $1.668^{\mathrm{b}}$ & 0.12 & $0.595^{\mathrm{a}}$ & 0.18 & $1.24^{\mathrm{c}}$ & 0.21 & $2.527^{\mathrm{d}}$ & 0.94 & $1.5075^{\mathrm{b}}$ & 0.810 & 0.211 & 0.009 \\
\hline Djf & $1.65^{\mathrm{a}}$ & 0.38 & $0.581^{\mathrm{a}}$ & 0.23 & $1.22^{\mathrm{a}}$ & 0.23 & $2.52^{\mathrm{a}}$ & 1.32 & $1.49275^{\mathrm{a}}$ & 0.814 & 0.206 & 0.842 \\
\hline FLO & $50.575^{a}$ & 6.78 & $29^{\mathrm{a}}$ & 2.45 & $120^{\mathrm{a}}$ & 15.25 & $111.667^{\mathrm{a}}$ & 9.89 & $77.8105^{\mathrm{a}}$ & 44.909 & 1.479 & 0.503 \\
\hline Fruct & $58.775^{\mathrm{a}}$ & 3.25 & $32.636^{\mathrm{a}}$ & 4.25 & $130^{\mathrm{a}}$ & 9.1 & $128.667^{\mathrm{a}}$ & 10.13 & $87.5195^{\mathrm{a}}$ & 49.451 & 1.125 & 0.555 \\
\hline Height & $57.715^{\mathrm{a}}$ & 5.01 & $25.818^{\mathrm{b}}$ & 4.7 & $60.95^{\mathrm{c}}$ & 7.28 & $66.9^{\mathrm{d}}$ & 5.78 & $52.84575^{\mathrm{a}}$ & 18.416 & 1.432 & 0.008 \\
\hline Nbrch & $4.97^{\mathrm{a}}$ & 2.02 & $3.136^{\mathrm{d}}$ & 1.73 & $7.85^{\mathrm{b}}$ & 2.34 & $4^{c}$ & 1.38 & $4.81525^{\mathrm{a}}$ & 2.081 & 6.827 & $<0.0001$ \\
\hline Nloc & $6.118^{\mathrm{a}}$ & 1.43 & $2.955^{\mathrm{a}}$ & 0.28 & $5^{\mathrm{a}}$ & 1.44 & $6.533^{\mathrm{a}}$ & 2.06 & $5.1515^{\mathrm{a}}$ & 1.601 & 1.011 & 0.575 \\
\hline Nepi & $10.3^{\mathrm{a}}$ & 2.34 & $4.864^{\mathrm{a}}$ & 1.02 & $5.15^{\mathrm{a}}$ & 2.19 & $8.633^{\mathrm{a}}$ & 2.57 & $7.23675^{\mathrm{a}}$ & 2.666 & 3.601 & 0.349 \\
\hline
\end{tabular}

Height: Plant height; Nbrch : Number of branch per plant ; Ljm : length of immature (horticultural maturity); Djf : Diameter of immature fruits ; Lfm : length of mature fruit; Dfm : diameter of mature fruits ; Nloc : number of locule ; Nepi : number of epicalyx ; Flo : Days to $50 \%$ flowering ; Fruct : days to $50 \%$ fruiting . On each line the values accompanied by different letters are significantly different at the probability threshold $(\alpha=0.05)$.

\section{Discussion}

The results of this work allowed us to highlight the existence of the great diversity of okra genetic resources in West Africa but also in other continents of the world. The variability observed within the varieties indicates that there are at least groups which are different from each other on the basis of the quantitative characters thus studied. It also allowed us to understand that 
even if the varieties are geographically distant some of them have morphological and genetic characters that are close to each other, which explains the different homogeneous groups obtained from the factorial discriminant analysis (AFD) and hierarchical ascending classification (CAH). However, cultivated varieties, even if they are genetically not very variable, have high potential for ecotypic differentiation due to abiotic and biotic stress (case of attack of nematodes and whitefly), which would need to be better exploited internationally (Sani, 2008). The study of wild relatives, in terms of phylogeny or possibilities of introgression, still little developed, also gives hope for further genetic progress.

Multivariate analyzes across the CAH and AFD showed that the variability of our accessions is structured in four groups on the basis of diameter of mature fruits (Dfm), Plant height (Height) and number of branch per plant (Nbrch) characters. It emerges from the high representativity of the first two canonical axes of the AFD (98.81\%), the existence of a strong genotypic and phenotypic organization of the studied material. The morphological and phenological dissimilarities observed between the different phenotypic groups suggest that accessions are maintained under very different evolutionary processes in their respective agroecosystems. Agroecosystems are likely to exert very selective pressure Genotype variables (Sadiki and Jarvis, 2005) as well as anthropogenic pressures (Robert et al., 2004). In fact, farmers' management of seeds such as selective sorting, post-harvest techniques and agricultural practices leads to selection leading to the maintenance or even the creation of significant phenotypic diversity (Robert et al. ., 2005).

These evolutionary factors could be the causes of the clear agromorphological and phenological differentiation observed between accessions. This constant evolution, influenced by the pedological, climatic and anthropic factors in the different agroecosystems, gives to the accessions characteristics of their own (Azam-Ali et al., 2001).

This type of observation, which shows the high intra-accession and inter-accession variability, has been described by several authors in different species cultivated in West Africa (Rouamba et al., 2001, Demol et al., 2002, Barnaud et al. al., 2007, Bakasso 2010, Antoine et al., 2012, Idi-saidou et al., 2014).

Okra (Abelmoschus spp. esculentus) and African okra (A. caillei) are well recognized vegetable crops of African and Asian continents. Although $A$. caillei cultivated in West and Central Africa (WCA) and account only 5\% of total world okra production, it is an important indigenous crop of humid and tropics (Siemonsma 1982a, b). Based on detail chromosome and crossing analysis African okra (A. caillei syn. Guineen type) was proposed to be an amphipolyploid derived from A. esculentus (common okra) and A. manihot 
(Siemonsama, 1982a ; Siemonsama, 1982b) and a hypothesis put forward that African okra is gradually replacing the common okra in the humid region of West Central Africa (Siemonsama 1882a). On the basis of further study on geographical distribution of $A$. esculentus and $A$. caillei showed that both are cultivated in most of the villages strat form Gulf of Guina to southern limit of Sahel, however, genetic integrity of these two species is not found to be threatned due to lack of spontaneous natural crossing between these two species (Hamon and Hamon 1992).

\section{Conclusion}

The variability observed within the accessions studied is an excellent argument for the conservation of traditional okra cultivars in the different areas of their production. This significant variability within the species could be favored its mode of reproduction. The place of local accessions in the plant resources of cultivated plants being no longer to be demonstrated, special attention must be paid to the regions that ensure the sustainability of this source of variability. The characters analyzed can thus constitute basic criteria for differentiating accessions from other producing regions of the species in Niger and can be used in morphological diversity studies of okra in West Africa and Asia. These results show the need to test the genetic approach by using molecular markers to better understand the global genetic diversity. This diversity compared with that identified by the perception of the farmers, but also to the diversity obtained after the phenotypic evaluation of the collected accessions allows a rational use of this resource in the programs of the improvement of the okra of Niger and those elsewhere.

\section{Acknowledgment}

This study was conducted with funding from the AVRDC-ICRISAT project. We thank the Word Vegetable Center (AVRDC) and the International Crops Research Institute for Semi-Arid Tropics (ICRISAT) for having authorized us to carry out our experimentation in their research stations of Sadoré and the University of Diffa for its contribution.

\section{References:}

1. Antoine, A.M., Adoukonou-Sagbadja, H., Rollande, A.D., Corneille, A., Clément, A. (2012): Impacts des pratiques culturales sur l'organisation génétique des sorghos cultivés par les Lokpa au NordOuest du Bénin révélés par les marqueurs SSRs. Journal of Applied Biosciences, 60: 4394-4409.

2. Azam-ali, S.N., Sesay, A., Karikari, S.K., Massawe, F.J., Aguilarmanjarrez, J., Bannayan, M., Hampson, K.J. (2001). Assessing the 
potential of an underutilized crop - A case study using bambara groundnut. Experimental Agriculture, 37: 433-472.

3. Bakasso, Y. (2010). Ressources génétiques des roselles (Hibiscus sabdariffa L.) du Niger : évaluations agromorphologique et génétique. Thèse de Doctorat d'état, université de Niamey, Niamey, p .139.

4. Barnaud, A. (2007). Savoirs, pratiques et dynamique de la diversité génétique : le sorgho (Sorghum bicolor ssp. bicolor) chez les Duupa du Nord Cameroun. Thèse de doctorat, université de Montpellier II, Montpellier, p. 282.

5. Camciu c, M., Bessifre, J.M., Vilarem, G., Gaset, A. (1998). Volatile components in okra seed coat. Phytochemistry 48: $311-315$.

6. Demol, J., Baudouin, J.P., Louant, B.P., Marechal, R., Mergeai, G., Otoul ,E. (2002). Amélioration des plantes. Application aux principales espèces cultivées en régions tropicales. Presses agronomiques de Gembloux, Gembloux, Belgique, 582 p.

7. DS/MDA. (2008): Annuaire des statistiques, Ministère du Développement Agricole. Niamey, Niger, 128 p.

8. Duzyaman, E. (1997) : Okra - Botany and Horticulture. Horticulture Review, 21:41-71.

9. Hamon S., Van Sloten D.H.(1995). Okra. ln: Evolution of crop plants (2nd ed.), 1. Smartt et N.W. Simmonds éd., Londres, Royaume-Uni, Longman, p. 350-357.

10. HAMON, S., CHARRIER, A. (1995). Discrimination de deux espèces de gombo cultivées en côte d'ivoire (Abelmoschus esculentus et Abelmoschus sp) sur la base de leurs profils enzymatiques. ORSTOM Adiopodoume, Rapport Multigraphié, 191 p.

11. Hamon, S., Hamon, P. (1992). Future prospects of the genetic integrity of two cultivated species of okra (A. esculentus and A. caillei; cultivated in West Africa Euphytica, 58:101-111.

12. Idi-Saidou. S., Yacoubou, B., Inoussa, M. M., Zaman-Allah. M., Atta. S., Barnaud, A., Billot, C., Saadou, M. (2014). Diversité agromorphologique des accessions de fonio [Digitaria exilis (Kippist.) Stapf.] au Niger. Int. J. Biol. Chem. Sci,. 8 (4) : 1710 - 1729

13. Kumar, S., Singh, V., Kumar, S., Singh, M., Rai, M., Kalloo, G.( 2011): RAPD protocol for tagging of fertility restorer and male sterility genes in chilli (Capsicum annuum L.).Veg. Sci. 29, 101-105.

14. McLachlan, G.J. (1992). Disriminant analysis and statistical pattern recognition, wiley, New York, 200 p.

15. Robert, T., Luxereau, A., Mariac, C., Ali, K., Allinne, C., Bani, J., Beidari, Y., Bezançon, G., Gayeux, S., Couturon, E., Dedieu, V., Sadou, M., Seydou, M., Seyni, O., Tidjani, M., Sarr, A. (2004). Gestion de la diversité en milieu paysan : influence de facteurs 
anthropiques et des flux de gènes sur la variabilité génétique des formes cultivées et spontanées du mil (Pennisetum glaucum ssp. glaucum) dans deux localités du Niger, Actes du 4 e colloque national. Le patrimoine génétique : la diversité et la ressource. La Châtre, 14-16 octobre 2002. Bureau des ressources génétiques 2004.

16. Robert, T., Mariac, C., Allinne, C., Ali, K., Beidari, Y., Bezançon, G., Couturon, E., Moussa, D., Sasou, M.S., Seydou, M., Seyni, O., Tidjani, M., Luxereau, A. (2005). Gestion des semences et dynamiques des introgressions entre variétés cultivées et entre formes domestiques et spontanées des mils (Pennisetum glaucum ssp. glaucum) au SudNiger. Les Actes du BRG, 5 e colloque national. Un dialogue pour la diversité. Lyon, 3-4-5 novembre 2004.

17. Rouamba, A., Sandmeier, M., Sarr, A., Ricroch, A. (2001). Allozyme variation within and among populations of onion (Allium cepa L.) from West Africa. Theoretical and Applied Genetics, 103: 855-861.

18. Sadiki, M., Jarvis, D. (2005). Conservation in situ de la diversité génétique des cultures par sa gestion à la ferme dans les agroécosystèmes marocains. Les Actes $d u B R G, 5:$ 445-464.

19. Sani, I.S. (2008) : Criblage de génotypes de gombo (Abelmoschus spp.) Pour leur résistance aux nématodes (Meloidogyne spp.). Mémoire de maitrise ès science naturelles, université de Niamey, 77p. 20. Siemonsma, J.S. (1882). Local okra cultivars from Ivory Coast. A note for the IBPGR. Centre Neerlandais, ORSTOM, Ivory Coast. 11p.

21. Siemonsma, J.S. (1982a). La culture du gombo (Abelmoschus spp.), légume-fruit tropical, avec référence spéciale à la Côte d'Ivoire. Thèse, université de Wageningen, Wageningen, Pays-Bas, 297 p.

22. Siemonsma, J.S. (1982b). West African okra: morphological and cytological indications for the existence of a natural amphiploid of Abelmoschus esculentus (L.) Moench and A. manihot (L.) Medikus. Euphytica, 31: 241-252. 